\title{
Article \\ A Novel Process for the Recovery of Betalains from Unsold Red Beets by Low-Temperature Enzyme-Assisted Extraction
}

\author{
Claudio Lombardelli, Ilaria Benucci *(D), Caterina Mazzocchi and Marco Esti (D) \\ Department of Agriculture and Forestry Science (DAFNE), Tuscia University, via S. Camillo de Lellis snc, \\ 01100 Viterbo, Italy; claudiolombardelli@libero.it (C.L.); catemaz@live.it (C.M.); esti@unitus.it (M.E.) \\ * Correspondence: ilaria.be@unitus.it
}

\begin{abstract}
Food waste management plays a central role in the circular economy. To our knowledge, only a few studies have investigated the use of unsold fruit and vegetables from supermarkets as a substitute source for the extraction of natural colorants. Thus, the aim of this paper was to suggest a green, tailored protocol that avoids the use of organic solvents for the recovery of betalains from unsold red beets for use as a food colorant. The recovery of such pigments was carried out by a tailored enzymatic mix, blended considering the polysaccharide composition of the beetroot cell wall; thus, it consisted of: cellulase (37\%), xylanase (35\%), and pectinase (28\%). The enzyme-assisted extraction protocol was optimized, and the most suitable conditions (in terms of pigment yield and color attributes) for the recovery of betalains from unsold beets appeared to be: $25 \mathrm{U} / \mathrm{g}$ total dose of enzymatic mix, temperature $25^{\circ} \mathrm{C}$, and processing time $240 \mathrm{~min}$.
\end{abstract}

Keywords: red beet; betalains; tailored enzymatic mix; extraction yield; color attributes

check for

updates

Citation: Lombardelli, C.; Benucci, I.; Mazzocchi, C.; Esti, M. A Novel Process for the Recovery of Betalains from Unsold Red Beets by Low-Temperature Enzyme-Assisted Extraction. Foods 2021, 10, 236. https://doi.org/10.3390/foods1002023

Received: 6 January 2021

Accepted: 19 January 2021

Published: 24 January 2021

Publisher's Note: MDPI stays neutral with regard to jurisdictional claims in published maps and institutional affiliations.

Copyright: (c) 2021 by the authors. Licensee MDPI, Basel, Switzerland. This article is an open access article distributed under the terms and conditions of the Creative Commons Attribution (CC BY) license (https:// creativecommons.org/licenses/by/ $4.0 /)$.

\section{Introduction}

Color is a distinctive characteristic of food and beverages. It is considered a quality indicator that affects their appeal to consumers [1]. During processing and storage, many foods are prone to color loss, thus requiring the addition of colorants to restore it [2]. In the last decade, the demand for natural pigments (believed to be less harmful than synthetic colorants) is increasing worldwide [3]. Moreover, coloring foodstuffs are considered ingredients, and can be indicated as "coloring fruit- and plant extracts" on food labels. Other additives must be declared by an E-number [3]. In this context, the global market for natural food coloring (USD 3.71 billion in 2017) is expected to grow at a Compound Annual Growth Rate (CAGR) of 5.7\% over the period of 2017-2023 [4].

From a Circular Economy approach, food waste (including unsold vegetables) is considered a promising source of natural colorants, sweeteners, antioxidants, and preservatives [5]. Among the natural pigments suitable as food coloring agents, the most attractive are anthocyanins, betalains, carminic acid, carotenoids, and chlorophylls [6]. Betalains are water-soluble, nitrogen-containing vacuolar pigments, derived from betalamic acid [7]. The nature of the residue associated with betalamic acid determines the classification of the pigment as red-violet betacyanin $(\lambda \sim 540 \mathrm{~nm})$ or yellow-orange betaxanthin $(\lambda \sim 480 \mathrm{~nm})$. Among betacyanins, the best-known is betanin, which gives the distinctive red color to red beets (Beta vulgaris ssp.); whereas, among betaxanthins, the best-known are vulgaxanthin, present in yellow beets (Betavulgaris L.), and indicaxanthin, found in cactus pears (Opuntia ficusindica) [8,9].

Although betalains and anthocyanins perform similar functions, they have never been reported in the same plant, seeming to be mutually exclusive in the plant kingdom. Betalains can also be found in roots, fruit, and flowers [10]. The food colorant known as 'beetroot red', extracted from beetroots, is commercialized in the European Union and United States as a food colorant (E162) [11], and it has several applications in food, including desserts and confectioneries, dry mixes, and dairy and meat products [12]. 
Globally, revenue from the beetroot powder market was valued at more than $\$ 15$ billion in 2016 and is expected to grow at a CAGR of 5\% between 2017 and 2027 [13].

Betalains have been recovered by various methods, such as diffusion-extraction, solidliquid extraction, reverse osmosis, and ultrafiltration [14]. Betalain-containing materials are generally soaked or ground. Pigments can be water-extracted; although, in most cases, the use of methanol or ethanol solutions $(20-50 \%)$ is required to complete the process. In addition, slight acidification of the extraction medium enhances betacyanin stability [15]. As described in the literature, the degree of cell membrane permeabilization is a major factor in determining extraction efficiency [16]. Recently, the development of an enzyme-assisted extraction procedure, based on tailored blending activities, has allowed us to improve plant cell-wall hydrolysis, thus raising the recovery yield of natural food colorants [5] and reducing the use of both solvents and energy [17]. It has been implemented for the extraction of colorants from grapes, alfalfa, marigold, safflower, strawberry, and red cherries [5,18]. Moreover, Naderi et al. [19] developed a selective, high-recovery approach based on the enzyme-assisted extraction of betalains from Hylocereus polyrhizus by the application of pectinase.

This research suggests a tailored protocol, based on targeted substrate-enzymatic extraction, for the recovery of betalains from unsold red beets. The procedure consists of applying a specific enzymatic mix that was designed on the basis of the composition of fully ripened red beet cell walls. Moreover, the optimal conditions (total dose of enzymatic mix, temperature, and processing time) for betalain recovery yield, as well as the colorimetric parameters of the extract, were identified.

\section{Materials and Methods}

\subsection{Red Beet}

Unsold beetroot (Beta vulgaris ssp.), devoid of visual blemishes and contaminations, was supplied by a local market (Unicoop Tirreno S.C., Viterbo, Lazio region, Italy). The raw material was washed, crushed in an HR 2068 blender (Philips S. P. A., Milan, Italy), and stored at $2-4{ }^{\circ} \mathrm{C}$ for 30 mins before use for betalains extraction.

\subsection{Enzymes and Chemicals}

Pectinase from Aspergillus niger containing both polygalacturonase (PG) and pectinliasic (PL) activity (83 I.U./g, [5]), cellulase from A. niger (CL, 18 I.U./g, [5]), and xylanase from Aspergillus oryzae (XL, 3 I.U./g, [5]) were supplied by Merck Group (Milan, Italy). All other reagents used were purchased from Merck (Milan, Italy). The specific activity of the abovementioned enzyme preparations was estimated using a previously described method [5].

\subsection{Red Beet Analysis}

\subsubsection{Chemico-Physical Parameters}

Beetroot samples were dried at $30^{\circ} \mathrm{C}$ for 5 days before dry matter (DM) and moisture determination [20]. $\mathrm{pH}$ and titratable acidity (TA) were measured following the method described by Desseva et al. [21] and Porto et al. [22].

\subsubsection{Total Sugar Content}

Total sugar content was analyzed by measuring absorbance at $620 \mathrm{~nm}$, following the Anthrone method $[5,23,24]$. The total sugar content $(\%)$ was determined through a calibration curve $\left(\mathrm{A}_{620 \mathrm{~nm}}=0.0047^{*}\right.$ glucose concentration; $\left.R^{2}=0.99\right)$ using a stock solution of glucose $(50-250 \mu \mathrm{g})$.

\subsubsection{Cell Wall Polysaccharide Composition}

The amount of cellulose, hemicellulose (xylans), and pectin in the beetroot was examined following Lombardelli et al. [5] after acid chemical hydrolysis [20]. 


\subsection{Enzyme-Assisted Extraction of Betalains}

The whole red beet samples (200 g) were washed, drained, and mixed (Phillip HR 2068 blender), and the resulting purée was used for the betalain extraction. The conditions of solid-liquid extraction were as follows: (i) 1:15 solid-liquid ratio between raw material and acetate buffer containing the multi-component enzyme mix (total dosage: 10, 18, 25, 38, and $50 \mathrm{U} / \mathrm{g}$ ); (ii) extraction temperature of 25 or $45^{\circ} \mathrm{C}$, at $\mathrm{pH} 5.5 \pm 0.1$; (iii) varied extraction duration up to five hours, with samples taken at various processing times. The mixture was then filtered and the extracts were analyzed. Trials were conducted in triplicates.

\subsection{Determination of Betalain Content}

The amount of betalain, in terms of betacyanins $(\mathrm{Bt})$ and betaxanthins $(\mathrm{Bx})$, was determined spectrophotometrically by visible spectra $(\lambda=340-700 \mathrm{~nm})$. Bt and Bx concentrations were calculated as described by Wruss et al. [25]:

$$
\mathrm{Bt}(\text { or Bx) content }(\mathrm{mg} / \mathrm{L})=\mathrm{A} \times \mathrm{DF} \times \mathrm{MW} \times 1000 / \varepsilon \times \mathrm{i}
$$

for Bt $\mathrm{A}_{536 \mathrm{~nm}}$ and $\varepsilon=60,000$ (molar extinction coefficient in $\mathrm{Lmol}^{-1} \mathrm{~cm}^{-1}$ ); for Bx $\mathrm{A}_{485 \mathrm{~nm}}$ and $\varepsilon=48,000\left(\mathrm{Lmol}^{-1} \mathrm{~cm}^{-1}\right)$; $\mathrm{DF}=$ dilution factor; molecular weight $(\mathrm{MW})=550 \mathrm{~g} / \mathrm{mol}$ (for $\mathrm{Bt}$ ) or $339 \mathrm{~g} / \mathrm{mol}$ (for $\mathrm{Bx}$ ); i = path length $(1 \mathrm{~cm})$. Samples were diluted and measured in triplicate.

\subsection{Color Measurements}

Color measurements were performed using a CR-5 colorimeter (Konica Minolta, Tokyo, Japan) with a D65 illuminant and CIE $L^{*} a^{*} b^{*}$ uniform color space, where $L^{*}$ represents lightness and darkness, $a^{*}$ indicates chromaticity on a green $\left(-a^{*}\right)$ to red $\left(+a^{*}\right)$ axis, and $b^{*}$ indicates the chromaticity on a blue $\left(-b^{*}\right)$ to yellow $\left(+b^{*}\right)$ axis. The analyses were performed in triplicate, with five measurements in each sample unit. Extracts were evaluated throughout in terms of redness index $\left(a^{*} / b^{*}\right)$, Chroma $\left(C^{*}=\left(a^{* 2}+b^{* 2}\right)^{0.5}\right)$, and hue angle $\left(h^{\circ}=\left(\arctan b^{*} / a^{*}\right)\right)$. The ratio $a^{*} / b^{*}$ was considered a good indicator of color loss in beetroot puree. The hue expresses the color nuance and the values are defined as follows: red-purple $=0^{\circ}$, yellow $=90^{\circ}$, bluish-green $=180^{\circ}$, and blue $=270^{\circ}$. The $C^{*}$ is a measure of chromaticity, which denotes the purity or saturation of the color; the higher the chroma values, the higher the perceived color intensity of the samples to the naked eye [26].

\subsection{Statistical Analysis}

Data were analyzed for statistical significance using a two-way analysis of variance (ANOVA) and a one-way ANOVA to check for an effect of the single factors (total dose of enzymatic mix and processing time) or an interaction with extraction yield and color parameters $(p<0.01)$. A Tukey's honestly significant difference (HSD) post-hoc test $(p<0.05)$ was carried out by the EXCEL ${ }^{\circledR}$ Add-in macro DSAASTAT program [27]. A Pearson correlation analysis was carried out on extraction yield and color attributes (expressed as "total betalain content" (Bt + Bx)); it was computed with GraphPad Prism 5.0 (GraphPad software, Inc., La Jolla, CA, USA) at a minimum significance level of $p<0.05$.

\section{Results and Discussion}

\subsection{Chemico-Physical Properties of Red Beets and Optimization of the Extraction Conditions}

Unsold red beets, used in this study for the recovery of betalains, were first analyzed in terms of moisture, $\mathrm{DM}, \mathrm{pH}, \mathrm{TA}$, total sugars, and cell-wall polysaccharide composition. The main chemico-physical parameters (in wet weight basis $\left.{ }_{(w w b}\right)$ ) of red beets were consistent with those reported in the literature [21] and were as below: moisture $89 \pm 1 \%_{\mathrm{wwb}}$; $\mathrm{DM} 11 \pm 1 \%_{\mathrm{wwb}} ; \mathrm{pH} 6.11 \pm 0.01$; TA $0.14 \pm 0.03$ (gcitric acid $/ 100 \mathrm{~g}_{\mathrm{wwb}}$ ); and total sugar content of $12 \mathrm{~g} / 100 \mathrm{~g}_{\mathrm{wwb}}$. These data demonstrate that the red beet used had the optimal ripening stage, which corresponds to the highest betalain amount [28]. 
The cell-wall polysaccharide composition (in dry weight basis $(\mathrm{dwb})$ ) was: cellulose $37 \%\left(4.0 \pm 0.1 \mathrm{~g} / 100 \mathrm{~g}_{\mathrm{dwb}}\right)$, pectin $28 \%\left(3.1 \pm 0.1 \mathrm{~g} / 100 \mathrm{~g}_{\mathrm{dwb}}\right)$, and hemicellulose $35 \%$ $\left(3.7 \pm 0.1 \mathrm{~g} / 100 \mathrm{~g}_{\mathrm{dwb}}\right)$. Cellulose was the predominant component, followed by hemicellulose and pectin. Zieminski et al. [29] and Spagnuolo et al. [30] reported similar results, highlighting that red beet pulp may contain $22 \%-30 \%$ cellulose and $24 \%-32 \%$ pectin, depending on variety. Hence, bearing in mind the red beet cell-wall composition, a tailored enzymatic mix (CL: 37\%; PG and PL: 28\%; and XL: 35\%) was fine-tuned. The proportion of each enzyme preparation in the multi-component mix was calculated with consideration to the corresponding enzymatic units (I.U./g).

The optimal conditions (temperature $(\mathrm{T})$ and $\mathrm{pH}$ ) for maximizing the activity of all the enzymes forming the tailored mix, assessed by response surface methodology analysis, were: temperature between 45 and $60{ }^{\circ} \mathrm{C}$ and $\mathrm{pH}$ between 5 and 6 , as demonstrated in a previous study [5]. Thus, all the extraction experiments were carried out at $45^{\circ} \mathrm{C}$ and $\mathrm{pH}$ 5.5. It is known that, under those conditions, betalains are quite stable [14]. Moreover, taking into account the strong influence of temperature on betalain stability (in particular for betacyanin), other experiments were conducted at $25^{\circ} \mathrm{C}$, considering that between 20 and $25{ }^{\circ} \mathrm{C}(\mathrm{pH}$ 4.5-6.5) enzyme preparations PG + PL and XL preserved a relative activity greater than $60 \%$ and CL showed a relative activity between 30 and $60 \%$, as shown by the overlay contour plot (Figure 1).

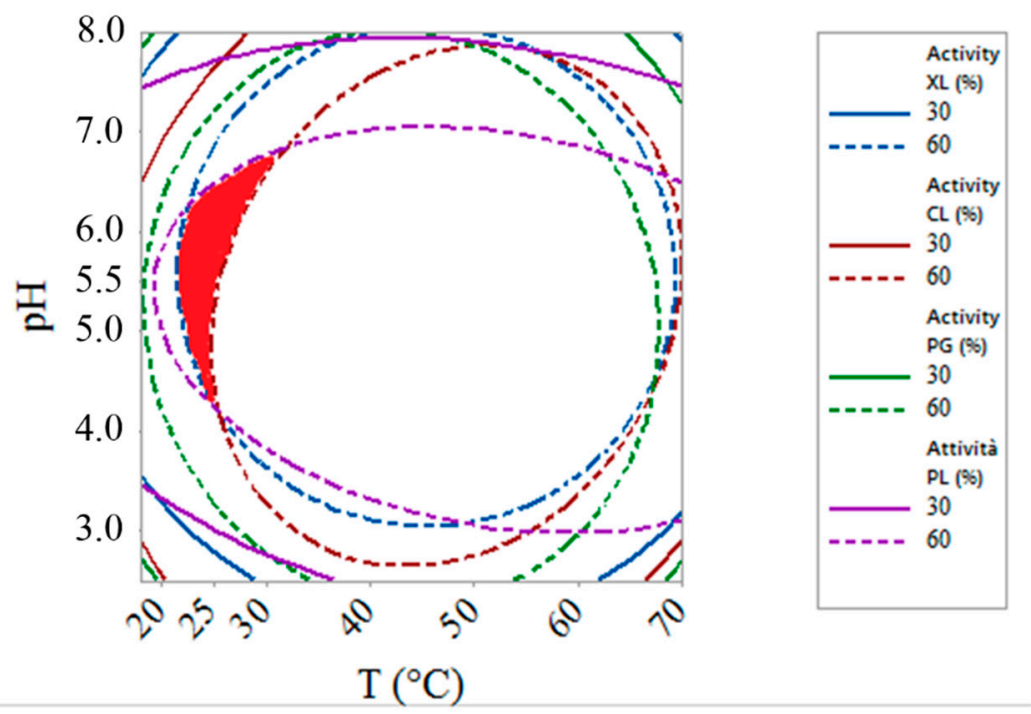

Figure 1. The optimum region, determined by overlaying contour plots of relative enzyme activity (polygalacturonase and pectin-liasic (PG + PL), cellulase (CL), and xylanase (XL)), evaluated as a function of temperature and $\mathrm{pH}$. The region highlighted in red is the area in which enzyme preparations PG + PL and XL preserved a relative activity $>60 \%$, whereas CL showed a relative activity between 30 and $60 \%$ (temperature $20-25^{\circ} \mathrm{C}$ and pH 4.5-6.5) (from Lombardelli et al., 2020 [5]).

\subsection{Influence of Different Enzyme Mix Dosages, Processing Times, and Temperatures on Betalain Extraction}

Nowadays, the recovery of stable natural pigments from food-waste-based matrixes is gaining attention, as described by Galanakis [31], Gupta et al. [32], and Ngamwonglumlert et al. [33]. This research suggests a need for a tailored protocol based on a targeted substrateenzymatic extraction that avoids the use of organic solvents for the recovery of betalains from unsold red beets. The specific enzymatic mix was designed on the basis of red beet cell-wall composition (CL: 37\%, PG and PL: 28\%, and XL: 35\%), and was applied at 45 and $25^{\circ} \mathrm{C}$, at $\mathrm{pH}$ 5.5. The processing time (20-300 $\mathrm{min}$ ) and total dose of enzymatic mix $(10-50 \mathrm{U} / \mathrm{g}$ ) were fine-tuned to improve the betalain recovery yield (in terms of $\mathrm{Bx}$ and $\mathrm{Bt}$ ). 
The two-way ANOVA (total dosage vs. processing time) demonstrated that Bx and Bt recovery yields were significantly affected by the investigated factors $(p<0.01$, data not shown). Moreover, data analyzed by means of one-way ANOVA (Figures 2 and 3) enabled us to test for significant differences between treatments involving each factor (total dosage or processing time). For all the tested total dosages (10-50 U/g), and regardless of the temperature applied $\left(45\right.$ or $\left.25^{\circ} \mathrm{C}\right)$, the $\mathrm{Bx}$ and Bt yield gradually increased at longer processing times, until reaching the highest value after $120 \mathrm{~min}$ at $45^{\circ} \mathrm{C}(\mathrm{Bx}=8.89 \pm 0.03$ and $\mathrm{Bt}=12.15 \pm 0.03(\mathrm{mg} / \mathrm{L}) / \mathrm{U}$ ) (Figure 2) and after $240 \mathrm{~min}$ at $25{ }^{\circ} \mathrm{C}$ for the dosage $25 \mathrm{U} / \mathrm{g}(\mathrm{Bx}=11.37 \pm 0.45$ and $\mathrm{Bt}=14.67 \pm 0.49(\mathrm{mg} / \mathrm{L}) / \mathrm{U})$ (Figure 3). These data prove that the enzymatic hydrolysis of cell-wall components was faster at $45^{\circ} \mathrm{C}$ compared with $25^{\circ} \mathrm{C}$, and mainly occurred within the first $2 \mathrm{~h}$ of incubation in all samples. The only exception appeared to be the treatment $10 \mathrm{U} / \mathrm{g}$ (Figure 2A), which required about $3 \mathrm{~h}$ to achieve the highest betalain extraction yield.

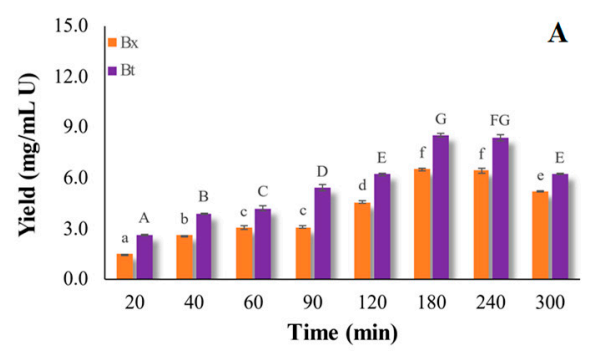

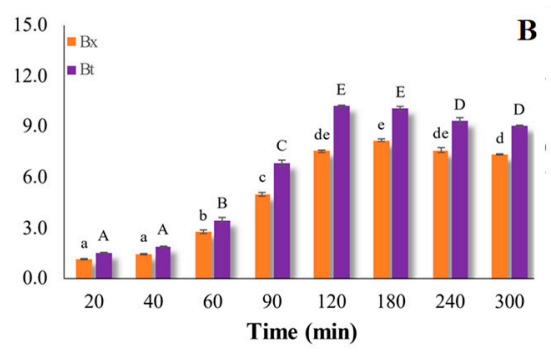

D

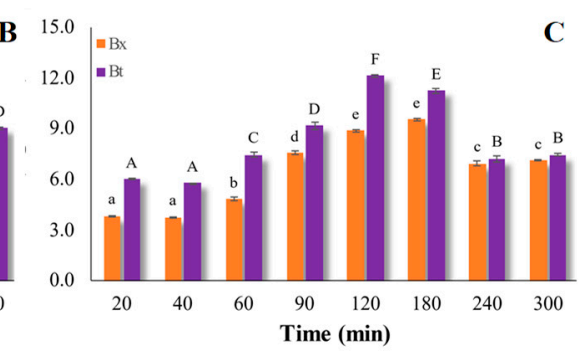

$\mathbf{E}$
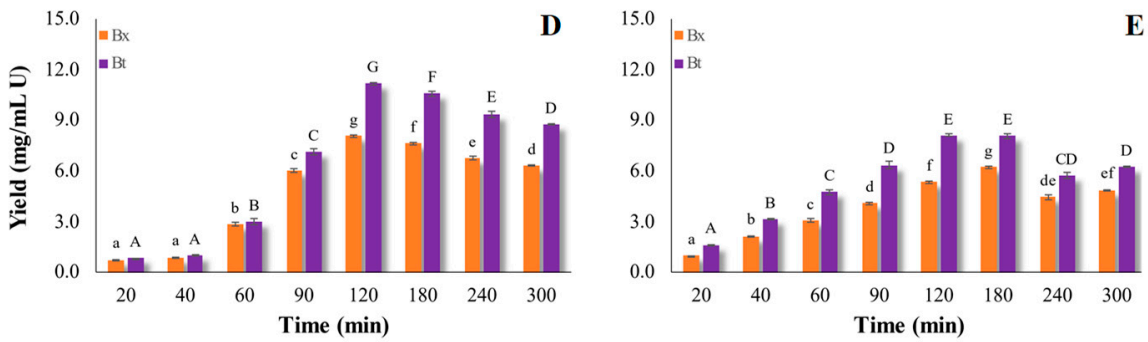

Figure 2. Extraction yield of betalains from unsold red beets at $45^{\circ} \mathrm{C}$ and $\mathrm{pH} 5.5$. Trials were performed using different total doses of enzymatic mix: (A) $10 \mathrm{U} / \mathrm{g}$, (B) $18 \mathrm{U} / \mathrm{g}$, (C) $25 \mathrm{U} / \mathrm{G}$, (D) $38 \mathrm{U} / \mathrm{g}$, and (E) $50 \mathrm{U} / \mathrm{g}$ for several processing times. For betacyanins $(\mathrm{Bt})$, means, indicated by capital letters, vary significantly (one-way variance analysis, $p=0.05$ ) with processing time. For betaxanthins (Bx), means, indicated by lower-case letters, vary significantly (one-way variance analysis, $p=0.05$ ) with processing time.

After $2 \mathrm{~h}$ at $45^{\circ} \mathrm{C}$, the recovery yield decreased, probably due to the weak stability of $\mathrm{Bt}$, which is strongly affected by temperature (Figure 2). In this regard, Havlikova et al. [34] proved that during the heating $\left(50^{\circ} \mathrm{C}\right)$ of betanin (a component of $\left.\mathrm{Bt}\right)$, the molecule is split, giving rise to cyclodopa and betalamic acid. Meanwhile, data in Figure 3 prove that at $25{ }^{\circ} \mathrm{C}$ and with longer processing times, the extraction yield did not decrease and no differences among samples were found. López et al. [35] reported that the extraction of betalains by pulsed electric fields at $30^{\circ} \mathrm{C}$ was more efficient than at $60{ }^{\circ} \mathrm{C}$, which can be explained by temperature-dependent pigment degradation reactions. Moreover, the betacyanin/betaxanthin ratio was not stable at $45^{\circ} \mathrm{C}$ during longer treatment times, while no changes in this ratio were revealed at $25^{\circ} \mathrm{C}$ (Figures 2 and 3). Prieto-Santiago et al. [26] explained that the variation in this ratio could be ascribable to the degradation of $\mathrm{Bt}$, as well as to the formation of Bx. Indeed, the latter could arise from the condensation of free amino acids with the betalamic acid, generated by Bt hydrolysis [26]. 

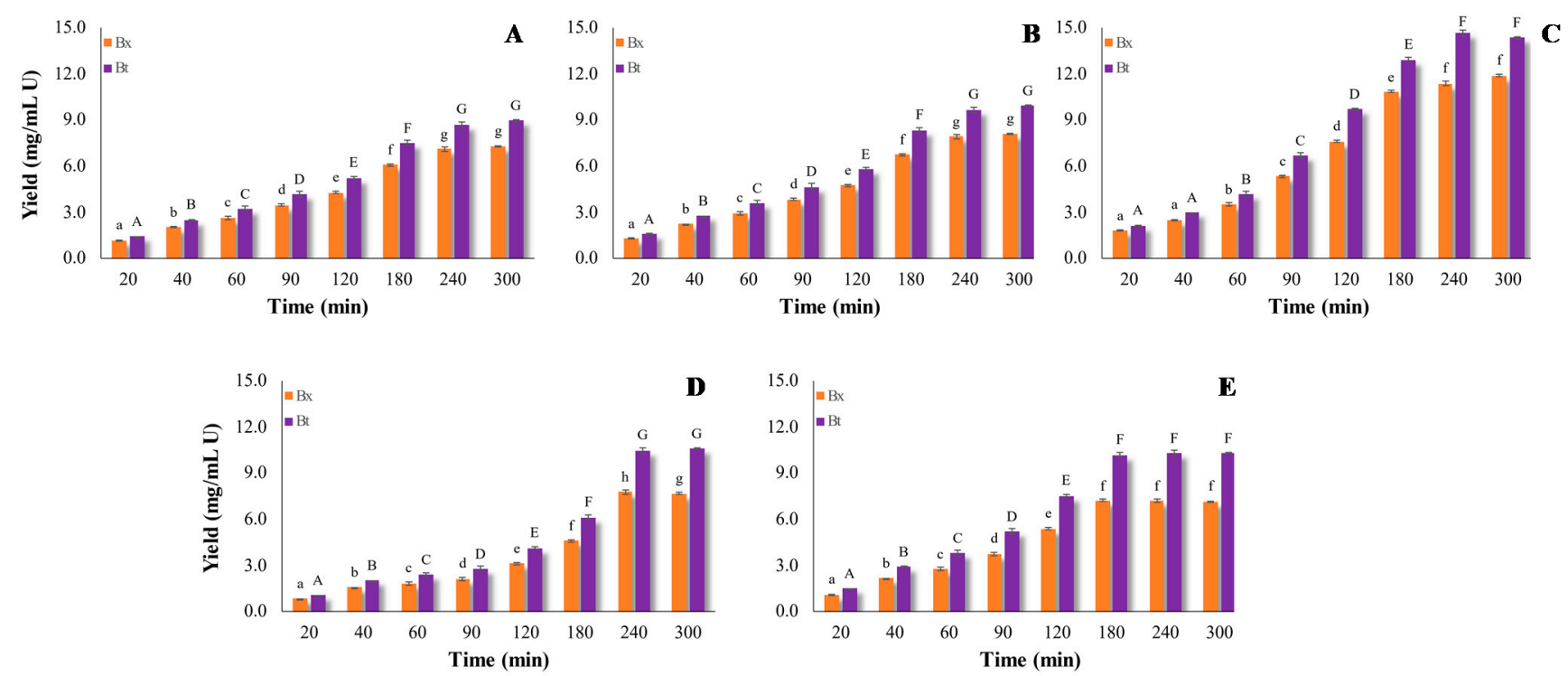

Figure 3. Extraction yield of betalains from unsold beetroot at $25^{\circ} \mathrm{C}$ and $\mathrm{pH}$ 5.5. Trials were performed using different total dosages of enzymatic mix: (A) $10 \mathrm{U} / \mathrm{g}$, (B) $18 \mathrm{U} / \mathrm{g}$, (C) $25 \mathrm{U} / \mathrm{G}$, (D) $38 \mathrm{U} / \mathrm{g}$, and (E) $50 \mathrm{U} / \mathrm{g}$, at several processing times. For betacyanins $(\mathrm{Bt})$, means, indicated by capital letters, vary significantly (one-way variance analysis, $p=0.05$ ) with processing time. For betaxanthins (Bx), means, indicated by lower-case letters, vary significantly (one-way variance analysis, $p=0.05$ ) with processing time.

Regardless of the extraction temperature $\left(45\right.$ or $\left.25^{\circ} \mathrm{C}\right)$, it is suggested that, at the lower tested dosages (10 and $18 \mathrm{U} / \mathrm{g}$ ), the small amount of pectinase activity may be not adequate to break down the pectin network and release pigments. Both at $45^{\circ} \mathrm{C}$ and at $25^{\circ} \mathrm{C}$, the minimal suitable total dosage was $25 \mathrm{U} / \mathrm{g}$. More specifically, at $45^{\circ} \mathrm{C}$, the extraction yield ranged from $3.83 \pm 0.01$ to $8.89 \pm 0.03$ after 20 and $120 \mathrm{~min}$ for $\mathrm{Bx}$, and from $6.03 \pm 0.01$ to $12.15 \pm 0.03$ after 20 and $120 \mathrm{~min}$ for Bt (Figure 2). Furthermore, at $25^{\circ} \mathrm{C}$, an extraction yield ranging from $1.82 \pm 0.01$ to $11.37 \pm 0.45$ after 20 and $240 \mathrm{~min}$ for Bx was observed, and from $2.14 \pm 0.01$ to $14.67 \pm 0.67$ for Bt after 20 and $240 \mathrm{~min}$ (Figure 3).

When a higher enzyme-mix dosage ( 38 and $50 \mathrm{U} / \mathrm{g}$ ) was used, the extraction yields decreased with respect to $25 \mathrm{U} / \mathrm{g}$, probably due to the fast hydrolysis degree, which may have led to inhibition of the end-product $[36,37]$.

Overall, the optimal extraction conditions for maximizing the recovery yield of Bt and Bx appeared to be $25^{\circ} \mathrm{C}$ for $240 \mathrm{~min}$ with an enzymatic-mix dosage of $25 \mathrm{U} / \mathrm{g}$.

\subsection{Color Characterization of Betalain Extracts}

The preservation of color properties is crucial in the development of a novel extraction protocol for the recovery of colorants from plant-based matrices. The color parameter's red-yellow ratio $\left(a^{*} / b^{*}\right.$, indicating the redness of the extract), chroma $\left(C^{*}\right.$, showing the dullness/vividness of the product), and hue angle $\left(h^{\circ}\right.$, the color perception by human eye), considered to be the best descriptors of color, were used to characterize the different betalain extracts recovered by the tailored enzymatic mix (Figure 4). 

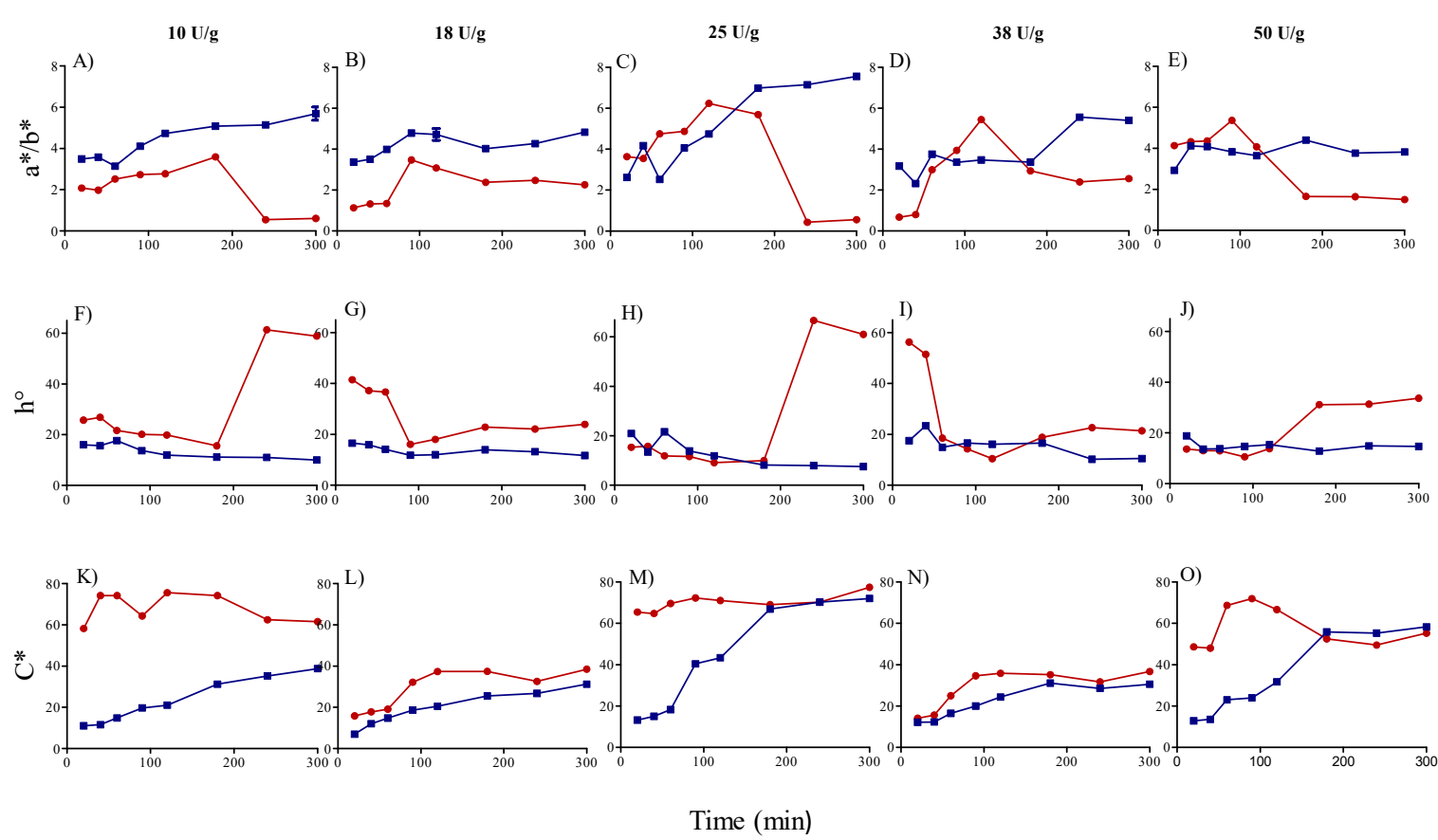

Figure 4. Color parameters $(\mathbf{A}-\mathbf{E}), a^{*} / b^{*}(\mathbf{F}-\mathbf{J})$, hue angle $\left(h^{\circ}\right)(\mathbf{K}-\mathbf{O})$, Chroma value $\left(C^{*}\right)$ of betalain extract recovered at $45^{\circ} \mathrm{C}(\bullet)$ and $25^{\circ} \mathrm{C}(\mathbf{\square})$, using different total doses of enzymatic mix (10-50 U/g).

Their values were in agreement with those reported in the literature (Prieto-Santiago et al., 2020) [26]. At $45^{\circ} \mathrm{C}$, regardless of the dosage used, $a^{*} / b^{*}$ increased as the extraction time increased until reaching the maximum value, beyond which a strong decrease at longer extraction times (in particular at 240 and $300 \mathrm{~min}$ ) was revealed. A similar trend was observed at $25^{\circ} \mathrm{C}$, despite $a^{*} / b^{*}$ not decreasing at longer extraction times (Figure $4 \mathrm{~A}-\mathrm{E}$ ). In particular, the highest values for the betalain extracts were recorded using the dosage $25 \mathrm{U} / \mathrm{g}$ after $120 \mathrm{~min}$ at $45{ }^{\circ} \mathrm{C}(6.24 \pm 0.04)$ and after $240 \mathrm{~min}$ at $25{ }^{\circ} \mathrm{C}(7.15 \pm 0.01)$ (Figure 4A-E).

Observed $h^{\circ}$ angle values were always lower for the extracts recovered at $25^{\circ} \mathrm{C}$ than for those obtained at $45^{\circ} \mathrm{C}$. More specifically, at $45^{\circ} \mathrm{C}$, the hue decreased slightly as the extraction time increased, and then significantly increased with longer times ( 240 and $300 \mathrm{~min}$ ) irrespective of the dosage used. At $25^{\circ} \mathrm{C}$, this parameter significantly decreased as the extraction time increased, and then remained constant (Figure $4 \mathrm{~F}-\mathrm{J}$ ). Considering that red-purple color has an $h^{\circ}$ near $0^{\circ}$, the best values of $h^{\circ}$ were revealed for the betalain extracts recovered using the dosage $25 \mathrm{U} / \mathrm{g}$ after $120 \mathrm{~min}$ at $45^{\circ} \mathrm{C}(9.11 \pm 0.05)$ and after $240 \mathrm{~min}$ at $25^{\circ} \mathrm{C}(7.96 \pm 0.01)$ (Figure $\left.4 \mathrm{~F}-\mathrm{J}\right)$.

The behavior of the above-described color parameters $\left(a^{*} / b^{*}\right.$ and $\left.h^{\circ}\right)$ could be explained by the aforementioned betacyanin degradation reactions, which resulted in a differential extraction of betacyanin vs. betaxanthin fractions (Figure 3). The thermal hydrolysis reactions at $45^{\circ} \mathrm{C}$ not only produced a decrease in tinctorial strength, but also a considerable color shift towards yellow nuance [26].

Concerning $C^{*}$, no clear trend was observed at $45^{\circ} \mathrm{C}$, whereas at $25{ }^{\circ} \mathrm{C}$ (regardless of the dosage used), a gradual rise in this parameter was evident as extraction time increased. The extracts recovered using the dosage $25 \mathrm{U} / \mathrm{g}$ were characterized by similar values of $C^{*}$, despite the processing time at $25^{\circ} \mathrm{C}\left(\mathrm{C}^{*}=70.30 \pm 0.08\right.$ after $\left.240 \mathrm{~min}\right)$ being 2 times longer than that at $45^{\circ} \mathrm{C}\left(\mathrm{C}^{*}=71.02 \pm 0.78\right.$ after $\left.120 \mathrm{~min}\right)$.

In order to suggest a novel, green, and sustainable biotechnological approach for the recovery of betalains from unsold red beets, the effects of enzymatic-mix dosage, processing time, and temperature on extraction yield and color attributes were considered. Accordingly, a correlational analysis between both dependent variables (extraction yield and color attributes) was conducted. Taking into account that measured color is determined 
by the contribution of both betacyanins and betaxanthins, the variable "total betalain content" $(\mathrm{Bt}+\mathrm{Bx})$ was used in the statistical analysis.

The color parameters $a^{*} / b^{*}$, chroma, and hue angle always appeared correlated (negatively or positively) with the total betalain content, regardless of the temperature and mix total dosage used (Table 1). Color parameters showed high correlation coefficients with the total betalain content at $25^{\circ} \mathrm{C}$ compared with $45^{\circ} \mathrm{C}$, and especially when a total dosage of $25 \mathrm{U} / \mathrm{g}$ was applied. In this case, $a^{*} / b^{*}$ and $C^{*}$ showed the strongest positive correlations (0.9478 and 0.9802), whereas $h^{\circ}$ angle had the strongest negative correlation $(-0.8823)$ (Table 1$)$. Accordingly, our results indicate that the $a^{*} / b^{*}$ ratio, hue angle, and chroma values may be linked to a higher betalain extraction yield.

Overall, the data reported in this paper, as well as the strong Pearson correlation coefficients, prove that the most suitable extraction conditions (in terms of yield and color attributes) for the recovery of betalains from unsold red beets are: a $25 \mathrm{U} / \mathrm{g}$ total dose of enzymatic mix; a temperature of $25^{\circ} \mathrm{C}$, and a processing time of $240 \mathrm{~min}$.

Table 1. Pearson correlation coefficients $(p<0.05)$ between total betalain content and color parameters in beetroot extracts for different enzyme-mix total dosages (10-50 U/g) at different temperatures (45 and $\left.25^{\circ} \mathrm{C}\right)$, estimated for the whole processing time (0-300 $\left.\mathrm{min}\right)$.

\begin{tabular}{cccc}
\hline Dosage (U/g) & Color Parameter & Betalain Content $\left(\mathbf{4 5}{ }^{\circ} \mathbf{C}\right)$ & Betalain Content $\left(\mathbf{2 5}{ }^{\circ} \mathbf{C}\right)$ \\
\hline \multirow{3}{*}{10} & $a^{*} / b^{*}$ & -0.0968 & 0.8077 \\
& $h^{\circ}$ & 0.3760 & -0.8050 \\
& $C^{*}$ & -0.0235 & 0.9505 \\
\hline \multirow{2}{*}{18} & $a^{*} / b^{*}$ & 0.7539 & 0.6181 \\
& $h^{\circ}$ & -0.8694 & -0.6557 \\
& $C^{*}$ & 0.9364 & 0.9612 \\
\hline \multirow{3}{*}{25} & $a^{*} / b^{*}$ & 0.6607 & 0.9478 \\
& $h^{\circ}$ & -0.1613 & -0.8823 \\
& $C^{*}$ & 0.6392 & 0.9802 \\
\hline \multirow{3}{*}{38} & $a^{*} / b^{*}$ & 0.7576 & 0.8928 \\
& $h^{\circ}$ & -0.8286 & -0.8043 \\
& $C^{*}$ & 0.873 & 0.9112 \\
\hline \multirow{2}{*}{50} & $a^{*} / b^{*}$ & -0.4401 & 0.4122 \\
& $h^{\circ}$ & 0.4852 & -0.4480 \\
& $C^{*}$ & -0.0059 & 0.9026 \\
\hline
\end{tabular}

\section{Conclusions}

The novel and significant contribution of the current research is the demonstration that the recovery of betalain from unsold red beets can be improved by applying a specific enzymatic mix based on the polysaccharide composition of the red-beet cell wall. Although the pigment extraction at higher temperatures $\left(45^{\circ} \mathrm{C}\right)$ was faster, a comparable recovery yield of betacyanin and betaxanthin fractions was achieved at lower temperatures $\left(25^{\circ} \mathrm{C}\right)$. Moreover, the low-temperature enzyme-assisted extraction protocol allowed better preservation of the color attributes of the betalain extracts.

Overall, the optimal conditions for the extraction of betalain from unsold red beets were: $25 \mathrm{U} / \mathrm{g}$ total dose of enzymatic mix, a temperature of $25^{\circ} \mathrm{C}$, and a processing time of $240 \mathrm{~min}$. These results prove that betalain recovery could be a "green route" to coloring foodstuffs, giving much greater value to unsold red beets.

Author Contributions: Conceptualization, C.L. and I.B.; methodology, C.L. and I.B.; validation, C.L., I.B., and M.E.; formal analysis, C.L. and C.M.; investigation, I.B., C.L., and I.B.; resources, I.B. and M.E.; data curation, C.L., C.M., and I.B.; writing-original draft preparation, C.L. and I.B.; writingreview and editing, M.E.; supervision, I.B. and M.E.; project administration, I.B. and M.E. funding acquisition, M.E. All authors have read and agreed to the published version of the manuscript.

Funding: This research received no external funding. 
Data Availability Statement: The data presented in this study are available on request from the corresponding author.

Acknowledgments: We are thankful to Unicoop Tirreno S.C. (Viterbo, Lazio region, Italy) for providing the unsold red beets (Beta vulgaris ssp.).

Conflicts of Interest: The authors declare no conflict of interest.

\section{References}

1. Cerreti, M.; Liburdi, K.; Del Franco, F.; Esti, M. Heat and light stability of natural yellow colourants in model beverage systems. Food Addit. Contam. 2020, 37, 905-915. [CrossRef] [PubMed]

2. Cortez, R.; Luna-Vital, D.A.; Margulis, D.; Gonzalez de Mejia, E. Natural pigments: Stabilization methods of anthocyanins for food applications. Compr. Rev. Food Sci. F 2017, 16, 180-198. [CrossRef] [PubMed]

3. Nath, P.; Kaur, C.; Rudra, S.G.; Varghese, E. Enzyme-assisted extraction of carotenoid-rich extract from red capsicum (Capsicum annuum). Agric. Res. 2016, 5, 193-204. [CrossRef]

4. McWilliams, A. Food Colors Market by Type (Natural, Synthetic, Nature-Identical), Application (Beverages, Processed Food, Bakery \& Confectionery Products, Oils \& Fats, Dairy Products, Meat, Poultry, Seafood), Form, Solubility, and Region-Global Forecast to 2023. 2018. Available online: https:/ / www.marketsandmarkets.com/Market-Reports/food-colors-market-36725323 .html (accessed on 20 December 2020).

5. Lombardelli, C.; Liburdi, K.; Benucci, I.; Esti, M. Tailored and synergistic enzyme-assisted extraction of carotenoid-containing chromoplasts from tomatoes. Food Bioprod. Process. 2020, 121, 43-53. [CrossRef]

6. Sigurdson, G.T.; Tang, P.; Giusti, M.M. Natural colorants: Food colorants from natural sources. Annu. Rev. Food Sci. T 2017, 8 , 261-280. [CrossRef]

7. Castellanos-Santiago, E.; Yahia, E.M. Identification and quantification of betalains from the fruits of 10 Mexican prickly pear cultivars by high-performance liquid chromatography and electrospray ionization mass spectrometry. J. Agric. Food Chem. 2008, 56, 5758-5764. [CrossRef]

8. Esatbeyoglu, T.; Wagner, A.E.; Schini-Kerth, V.B.; Rimbach, G. Betanin-A food colorant with biological activity. Mol. Nutr. Food Res. 2015, 59, 36-47. [CrossRef]

9. Hussain, E.A.; Sadiq, Z.; Zia-Ul-Haq, M. Bioavailability of betalains. In Betalains: Biomolecular Aspects; Springer: Cham, Switzerland, 2018; pp. 165-183.

10. Gandía-Herrero, F.; García-Carmona, F. Biosynthesis of betalains: Yellow and violet plant pigments. Trends Plant Sci. 2013, 18, 334-343. [CrossRef]

11. Castellar, M.R.; Obon, J.M.; Fernandez-Lopez, J.A. The isolation and properties of a concentrated red-purple betacyanin food colourant from Opuntia stricta fruits. J. Sci. Food Agric. 2006, 86, 122-128. [CrossRef]

12. Sáenz, C.; Cancino, B.; Robert, P. Red betalains from Opuntia spp.: Natural colorants with potential applications in foods. Isr. J. Plant Sci. 2012, 60, 291-299.

13. Ciriminna, R.; Fidalgo, A.; Danzì, C.; Timpanaro, G.; Ilharco, L.M.; Pagliaro, M. Betanin: A bioeconomy insight into a valued betacyanin. ACS Sustain. Chem. Eng. 2018, 6, 2860-2865. [CrossRef]

14. Azeredo, H.M. Betalains: Properties, sources, applications, and stability-a review. Int. J. Food Sci. Tech. 2009, 44, 2365-2376. [CrossRef]

15. Delgado-Vargas, F.; Jimenez, A.R.; Paredes-Lopez, O. Natural pigments: Carotenoids, anthocyanins, and betalains -characteristics, biosynthesis, processing, and stability. Crit. Rev. Food Sci. Nutr. 2000, 40, 173-289. [CrossRef] [PubMed]

16. Fincan, M.; DeVito, F.; Dejmek, P. Pulsed electric field treatment for solid-liquid extraction of red beetroot pigment. J. Food Eng. 2004, 64, 381-388. [CrossRef]

17. Sowbhagya, H.B.; Chitra, V.N. Enzyme-assisted extraction of flavorings and colorants from plant materials. Crit. Rev. Food Sci. Nutr. 2010, 50, 146-161. [CrossRef] [PubMed]

18. Ahmadi, M.; Heidari, O.; Mohammadi Nafchi, A.R. Optimization of lycopene extraction from tomato waste with the integration of ultrasonic-enzymatic processes by response surface methodology. J. Ind. Eng. Int. 2015, 1, 29-34.

19. Naderi, N.; Stintzing, F.C.; Ghazali, H.M.; Manap, Y.A.; Jazayeri, S.D. Betalain extraction from Hylocereus polyrhizus for natural food coloring purposes. J. Prof. Assoc. Cactus Dev. 2010, 12, 143-154.

20. Ververis, C.; Georghiou, K.; Danielidis, D.; Hatzinikolaou, D.G.; Santas, P.; Santas, R.; Corleti, V. Cellulose, hemicelluloses, lignin and ash content of some organic materials and their suitability for use as paper pulp supplements. Bioresour. Technol. 2007, 98, 296-301. [CrossRef]

21. Desseva, I.; Stoyanova, M.; Petkova, N.; Mihaylova, D. Red Beetroot Juice Phytochemicals Bioaccessibility: An In Vitro Approach. Pol. J. Food Nutr. Sci. 2020, 70, 45-53. [CrossRef]

22. Porto, M.R.A.; Okina, V.S.; Pimentel, T.C.; Prudencio, S.H. Physicochemical stability, antioxidant activity, and acceptance of beet and orange mixed juice during refrigerated storage. Beverages 2017, 3, 36. [CrossRef]

23. De Bruyn, J.W.; Van Keulen, H.A.; Ferguson, J.H.A. Rapid method for the simultaneous determination of glucose and fructose using anthrone reagent. J. Sci. Food Agric. 1968, 19, 597-601. [CrossRef] 
24. Austin, R.B. Diurnal changes in the sugar and organic anion concentrations in red beet leaves. Ann. Bot. 1972, 36, 475-783. [CrossRef]

25. Wruss, J.; Waldenberger, G.; Huemer, S.; Uygun, P.; Lanzerstorfer, P.; Müller, U.; Weghuber, J. Compositional characteristics of commercial beetroot products and beetroot juice prepared from seven beetroot varieties grown in Upper Austria. J. Food Compos. Anal. 2015, 42, 46-55. [CrossRef]

26. Prieto-Santiago, V.; Cavia, M.M.; Alonso-Torre, S.R.; Carrillo, C. Relationship between color and betalain content in different thermally treated beetroot products. J. Food Sci. Technol. 2020, 57, 3305-3313. [CrossRef] [PubMed]

27. Onofri, A. Enhancing Excel capability to perform statistical analyses in agriculture applied research. In Computational Statistics and Data Analysis-Statistical Software Newsletters; International Association for Statistical Computing: The Hague, The Netherlands, 2006.

28. Montes-Lora, S.; Rodríguez-Pulido, F.J.; Cejudo-Bastante, M.J.; Heredia, F.J. Implications of the red beet ripening on the colour and betalain composition relationships. Plant Foods Hum. Nutr. 2018, 73, 216-221. [CrossRef] [PubMed]

29. Ziemiński, K.; Romanowska, I.; Kowalska, M. Enzymatic pretreatment of lignocellulosic wastes to improve biogas production. Waste Manag. 2012, 32, 1131-1137. [CrossRef]

30. Spagnuolo, M.; Crecchio, C.; Pizzigallo, M.D.; Ruggiero, P. Fractionation of sugar beet pulp into pectin, cellulose, and arabinose by arabinases combined with ultrafiltration. Biotechnol. Bioeng. 1999, 64, 685-691. [CrossRef]

31. Galanakis, C.M. Recovery of high added-value components from food wastes: Conventional, emerging technologies and commercialized applications. Trends Food Sci. Technol. 2012, 26, 68-87. [CrossRef]

32. Gupta, N.; Poddar, K.; Sarkar, D.; Kumari, N.; Padhan, B.; Sarkar, A. Fruit waste management by pigment production and utilization of residual as bioadsorbent. J. Environ. Manag. 2019, 244, 138-143. [CrossRef]

33. Ngamwonglumlert, L.; Devahastin, S.; Chiewchan, N. Natural colorants: Pigment stability and extraction yield enhancement via utilization of appropriate pretreatment and extraction methods. Crit. Rev. Food Sci. Nutr. 2017, 57, 3243-3259. [CrossRef]

34. Havlíková, L.; Miková, K.; Kyzlink, V. Heat stability of betacyanins. Z. Lebensm. Unters. Forsch. 1983, 177, 247-250. [CrossRef]

35. López, N.; Puértolas, E.; Condón, S.; Raso, J.; Alvarez, I. Enhancement of the extraction of betanine from red beetroot by pulsed electric fields. J. Food Eng. 2009, 90, 60-66. [CrossRef]

36. Çinar, I. Effects of cellulase and pectinase concentrations on the colour yield of enzyme extracted plant carotenoids. Process Biochem. 2005, 40, 945-949. [CrossRef]

37. Ranveer, R.C.; Patil, S.N.; Sahoo, A.K. Effect of different parameters on enzyme-assisted extraction of lycopene from tomato processing waste. Food Bioprod. Process. 2013, 91, 370-375. [CrossRef] 